\title{
Implementasi Education for Sustainable Development (ESD) dalam pembelajaran IPA di Kabupaten Garut: sebuah studi pendahuluan
}

\author{
Shinta Purnamasari ${ }^{1 *}$, Fitri Azkia Fahmi Suhendi ${ }^{2}$, Neng Leli Nailul Zulfah ${ }^{3}$ \\ Prodi Pendidikan IPA Universitas Garut, Jalan Raya Samarang No. 52 A, Garut 44151 \\ 1'shintapurnamasari@uniga.ac.id*; azkiaf282@gmail.com; nailulzulfah01@gmail.com \\ *korespondensi penulis
}

Received: 15 January 2022

ARTICLE HISTORY

Revised: 07 February 2022

Accepted: 14 February 2022

\begin{abstract}
ABSTRAK
Education for Sustainable Development (ESD) merupakan suatu cara yang dapat diterapkan dalam rangka pencapaian Sustainable Development Goals (SDGs). Mata pelajaran IPA dapat berkontribusi dalam ESD melalui pengintegrasian kompetensi-kompetensi ESD dalam topik-topik IPA. Penelitian ini merupakan studi pendahuluan yang bertujuan untuk mengetahui keterlaksanaan implementasi ESD dalam pembelajaran IPA pada tingkat SMP di Kabupaten Garut. Instrumen yang digunakan dalam penelitian ini adalah angket yang disebar secara online kepada guru IPA SMP. Berdasarkan angket, persentase implementasi ESD dalam pembelajaran IPA yang dilakukan oleh guru adalah 25\%. implementasi ESD dalam pembelajaran IPA paling banyak diintegrasikan pada topik bioteknologi. Salah satu faktor penghambat implementasi ESD dalam pembelajaran IPA adalah keterbatasan pemahaman guru terhadap ESD dan SDGs.
\end{abstract}

Kata kunci : Education for Sustainable Development, ESD dalam pembelajaran IPA, ESD

\begin{abstract}
Implementation of Education for Sustainable Development in science learning in Garut regency: a preliminary study. Education for Sustainable Develompment is a one way that can be applied in the context of achieving the Sustainable Development Goals (SDGs). Science can be contributu to ESD through integrating ESD competencies into science topics. This study was a preliminary study that aims to determine the implementation of ESD in science learning at the middle school in Garut Regency. The instrument used in this study was a questionnaire which distributed online to middle school science teachers. Based on questionnaire, the percentage of ESD implementation in science learning carried by the teachers was $25 \%$. The implementation of ESD in science learning mostly integrated on the biotechnology topic. One of the inhibiting factors for the implementation ESD in science learning is the teachers do not fully understand about ESD and SDGs.
\end{abstract}

Key word: Education for Sustainable Development, ESD in science learning, ESD

\section{Pendahuluan}

Dewasa ini, pembangunan berkelanjutan telah menjadi isu penting dalam mempersiapkan masyarakat global untuk menghadapi tantangan yang hadir akibat adanya perubahan lingkungan yang terjadi secara global. Pendidikan untuk pembangunan berkelanjutan atau Education for Sustainable Development (ESD) merupakan suatu cara yang dapat diterapkan dalam rangka pencapaian Sustainable Development Goals (SDGs) melalui pendidikan. Pendidikan memiliki tanggung jawab untuk mempersiapkan setiap orang dalam menghadapi dan menjawab tantangan abad ke-21, serta menumbuhkan nilai dan keterampilan yang tepat yang akan mengarah pada pembangunan yang berkelanjutan. ESD memiliki kerangka kerja yang yang bertujuan untuk meningkatkan peran dan kontribusi bidang pendidikan dalam membangun masyarakat yang lebih adil dan dunia yang berkelanjutan. ESD tidak hanya mendukung pengintegrasian pembangunan bekelanjutan dan SDGs ke dalam pendidikan dan pembelajaran, tetapi juga memastikan integrasi pendidikan dan pembelajaran ke dalam setiap kegiatan yang mendukung pembangunan berkelanjutan dan SDGs (Purnamasari \& Hanifah, 2021; UNESCO, 2020).

ESD diyakini dapat memastikan semua orang mendapatkan pengetahuan, sikap, nilai, dan keterampilan untuk masa depan berkelanjutan yang lebih baik. Dengan bekal yang telah diperoleh, diharapkan mereka dapat mengolah dan memproses informasi yang diterima untuk membantu mereka dalam membuat keputusan dan respons yang bertanggung jawab terkait kelangsungan ekonomi, kelangsungan ekosistem, dan kelangsungan masyarakat yang adil (Hariyono et al., 2018; Klarin, 2018; 
Novidsa et al., 2020; UNESCO, 2017). Selain itu, ESD juga diyakini dapat menjadi sebuah penyelesaian terkait permasalahan yang kompleks bagi generasi saat ini dan yang akan datang karena ESD memberikan wawasan yang luas dan jangka panjang mengenai lingkungan secara global (Novidsa et al., 2020; Purnamasari \& Hanifah, 2021; Rahman et al., 2019).

Menurut Hariyono et al. (2018), ESD merupakan sebuah inovasi baru yang sangat potensial untuk diterapkan dan dikembangkan di Indonesia. ESD dapat diintegrasikan ke dalam kurikulum pada semua jenjang pendidikan, mulai dari jenjang dasar, menengah, sampai jenjang pendidikan tinggi. ESD juga bersifat interdisipliner dan transdisipliner (Sund \& Gericke, 2020; UNESCO, 2018), sehingga semua disiplin ilmu dapat berkontribusi pada ESD baik secara mandiri maupun kolaborasi, salah satunya adalah mata pelajaran Ilmu Pengetahuan Alam (IPA) yang terdapat pada semua jenjang pendidikan. Menurut Eilks (2015), IPA dapat berkontribusi dalam membentuk pemahaman siswa terkait alam dan kekayaannya, sehingga setelah mempelajarinya siswa dapat berperan aktif dalam upaya-upaya konservasi lingkungan. Sejalan dengan hal itu, Wilujeng et al. (2019) mengemukakan bahwa IPA dapat meningkatkan kesadaran dan perubahan sikap positif dari siswa terkait lingkungan dan diharapkan ke depannya mampu menciptakan dampak yang positif terhadap kelestarian alam dan lingkungan.

Berangkat dari sudut pandang ini, kita dapat melihat urgensi dari implementasi ESD dalam pembelajaran IPA. Keberhasilan dan kualitas dari implementasi ESD dalam pembelajaran IPA dipengaruhi oleh berbagai faktor, salah satunya adalah kemampuan dan keterampilan guru dalam merancang RPP yang merupakan salah satu komponen penting dan mendasar untuk guru profesional (Hariyono et al., 2018). Arah dari penelitian ini menitikberatkan pada kemampuan guru mata pelajaran IPA dalam mengimplementasikan ESD melalui pengembangan perangkat pembelajaran yang mengintegrasikan kompetensi ESD. Untuk memperoleh gambaran terkait kemampuan guru mata pelajaran IPA dalam mengimplementasikan ESD diperlukan data awal terkait keterlaksanaan implementasi ESD yang diperoleh melalui sebuah studi pendahuluan. Oleh karena itu, penelitian ini merupakan suatu studi pendahuluan yang bertujuan untuk mengetahui keterlaksanaan implementasi ESD atau pengintegrasian kompetensi ESD ke dalam pembelajaran IPA pada tingkat SMP di Kabupaten Garut.

\section{Metode}

Penelitian ini merupakan suatu studi pendahuluan yang menggunakan metode deskriptif kuantitatif. Subjek penelitian ini adalah 11 guru mata pelajaran IPA pada tingkat SMP di Kabupaten Garut. Profil responden penelitian ini dapat dilihat pada tabel 1. Pengumpulan data dilakukan menggunakan instrumen angket yang diberikan secara online melalui Google formulir untuk setiap subjek. Kemudian data dianalisis dan diubah ke dalam bentuk persentase yang kemudian diinterpretasikan menjadi sebuah penjelasan deskriptif.

Tabel 1. Profil responden guru IPA SMP

\begin{tabular}{clcc}
\hline \multirow{2}{*}{ Responden } & \multicolumn{3}{c}{ Variabel } \\
\cline { 2 - 4 } & Jenis kelamin & Pendidikan terakhir & Pengalaman mengajar \\
\hline 1 & Perempuan & Magister (S2) & $6-10$ tahun \\
2 & Laki-laki & Sarjana $(\mathrm{S} 1)$ & $6-10$ tahun \\
3 & Perempuan & Sarjana $(\mathrm{S} 1)$ & $11-15$ tahun \\
4 & Perempuan & Magister (S2) & $1-5$ tahun \\
5 & Perempuan & Sarjana $(\mathrm{S} 1)$ & $>20$ tahun \\
6 & Perempuan & Sarjana $(\mathrm{S} 1)$ & $1-5$ tahun \\
7 & Laki-laki & Magister (S2) & $>20$ tahun \\
8 & Perempuan & Sarjana $(\mathrm{S} 1)$ & $6-10$ tahun \\
9 & Perempuan & Sarjana $(\mathrm{S} 1)$ & $11-15$ tahun
\end{tabular}




\begin{tabular}{lllc}
10 & Laki-laki & Sarjana (S1) & $>20$ tahun \\
11 & Perempuan & Sarjana (S1) & 11-15 tahun \\
12 & Laki-laki & Sarjana (S1) & 6-10 tahun \\
\hline
\end{tabular}

\section{Hasil dan Pembahasan}

ESD ini dapat dikatakan sebagai sebuah inovasi dalam pembelajaran IPA karena menciptakan suatu pendekatan baru dalam pendidikan dan pembelajaran IPA. Pendekatan ini dapat membawa kultur dan arah yang baru bagi dunia pendidikan, baik dalam segi konten maupun metode pembelajaran (Dannenberg \& Grapentin, 2016). Secara global, ESD semakin diakui sebagai elemen utama dari pendidikan berkualitas tinggi. Hal ini terlihat jelas dalam pelibatan ESD sebagai bagian dari 2030 Agenda for Sustainable Development yang disetujui oleh 195 negara (UNESCO, 2017, 2020). Sebagai guru IPA profesional dituntut untuk mampu mengikuti dan mengimbangi perkembangan ilmu pengetahuan dan teknologi, termasuk ESD ini. Guru IPA harus mampu mengembangkan dan menerapkan pendekatan, metode, dan strategi pembelajaran yang mengintegrasikan kompetensikompetensi ESD dalam proses pembelajaran.

Dalam penelitian ini, dilakukan survey untuk melihat keterlaksanaan implementasi ESD atau pengintegrasian kompetensi-kompetensi ESD ke dalam pembelajaran IPA pada tingkat SMP, khususnya di Kabupaten Garut. Informasi terkait keterlaksanaan ini digunakan untuk mengetahui seberapa sering dan pada topik IPA apa saja implementasi ESD dilakukan dalam pembelajaran IPA. Berdasarkan angket yang diberikan kepada guru IPA SMP di Kabupaten Garut, diperoleh informasi bahwa 75\% guru belum pernah mengimplementasikan ESD dalam pembelajaran IPA di sekolah (grafik 1). Ini menunjukkan bahwa dari 12 guru, baru 3 guru saja yang sudah pernah mengimplementasikan ESD atau mengintegrasikan kompetensi ESD ke dalam pembelajaran IPA, sedangkan 9 guru lainnya belum pernah. Melalui penelusuran lebih lanjut terhadap 9 guru IPA yang belum pernah mengimplementasikan ESD, diperoleh informasi bahwa guru-guru belum terlalu memahami mengenai ESD, bahkan 3 di antaranya memaparkan bahwa mereka tidak mengetahui apa itu ESD.

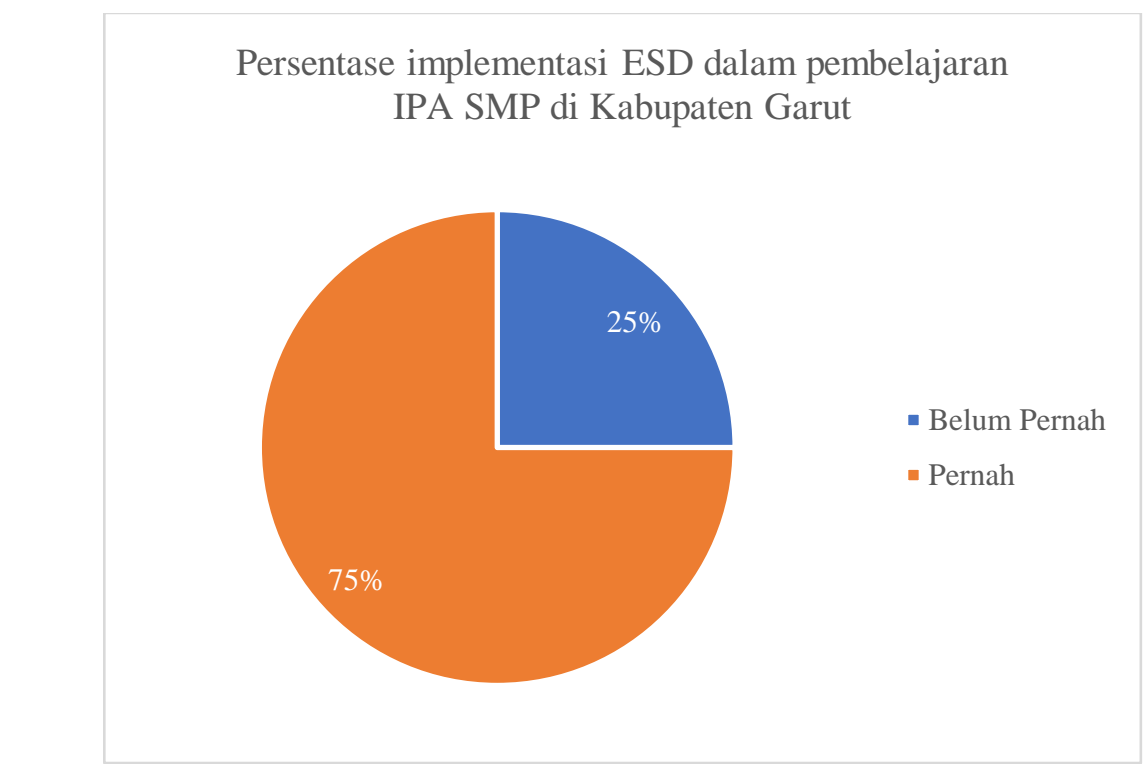

Gambar 1. Diagran keterlaksanaan implementasi ESD dalam pembelajaran IPA SMP.

Berdasarkan angket, ditemukan bahwa guru IPA belum semuanya mengetahui ESD, terutama SDGs. Hanya ada satu guru yang dapat menyebutkan bahwa terdapat 17 SDGs, sedangkan 11 guru lainnya memberikan jawaban yang beragam. Berdasarkan angket juga ditemukan bahwa terdapat guru yang masih mengalami kesulitan membedakan SDGs yang berjumlah 17 dengan 4 dimensi 
pembangunan berkelanjutan, sehingga mereka menjawab bahwa terdapat 4 tujuan pembangunan berkelanjutan atau SDGs. Hal ini tentu menjadi salah satu faktor penghambat atau kendala yang dialami oleh guru dalam mengimplementasikan ESD. Implementasi ESD merupakan upaya pencapaian SDGs melalui peningkatan pemahaman 17 SDGs dalam konteks pendidikan, meningkatkan pemahaman kritis dan kontekstual dari SDGs, dan mengarahkan aktivitas pembelajaran untuk pencapaian SDGs. Oleh karena itu, dalam mengimplementasikan ESD pada pembelajaran, guru IPA dituntut untuk memahami SDGs dan capaian-capaian terukurnya agar kompetensi-kompetensi ESD dapat terintegrasikan dalam pembelajaran dan memberikan wawasan terkait pembangunan berkelanjutan yang komprehensif. (Jegstad \& Sinnes, 2015; Karaarslan \& Teksöz, 2016; UNESCO, 2020).

Pada tabel 2 disajikan data terkait frekuensi dan topik IPA yang digunakan oleh guru dalam mengimplementasikan ESD. Berdasarkan tabel 2, implementasi ESD dalam pembelajaran IPA yang dilaksanakan oleh masing-masing guru telah dilakukan lebih dari satu kali dan pada topik-topik yang beragam. Hal ini menunjukkan bahwa mata pelajaran IPA sangat potensial untuk pengimplementasian ESD (Kyle, 2020; Rahmawati et al., 2021). Topik IPA yang banyak diambil oleh guru dalam mengimplementasikan ESD adalah bioteknologi. Topik atau materi bioteknologi dinilai sangat cocok untuk diintegrasikan dengan kompetensi-kompetensi ESD, karena pada topik bioteknologi melibatkan teknik-teknik atau teknologi yang dapat digunakan dalam rangka pemenuhan kebutuhan atau kepentingan umat manusia, baik untuk saat ini maupun masa depan (Indrati \& Hariadi, 2016).

Tabel 2. Sebaran topik IPA dalam implementasi ESD

\begin{tabular}{|c|c|c|}
\hline \multirow{2}{*}{ Responden } & \multicolumn{2}{|r|}{ Implementasi ESD } \\
\hline & Frekuensi & Topik IPA \\
\hline 5 & 2 kali & Bioteknologi \\
\hline 6 & $>3$ kali & $\begin{array}{c}\text { Ekologi, sistem organ manusia, reproduksi tumbuhan dan hewan, } \\
\text { bioteknologi }\end{array}$ \\
\hline 7 & $>3$ kali & $\begin{array}{c}\text { Bioteknologi, energi listrik, zat dan wujudnya, kemagnetan, listrik } \\
\text { statis }\end{array}$ \\
\hline
\end{tabular}

Meskipun berdasarkan angket keterlaksanaan implementasi ESD dalam pembelajaran IPA masih memiliki persentase yang rendah, para guru IPA menyatakan bahwa mereka siap untuk mengimplementasikan ESD dalam pembelajaran IPA di kelas. Sebagian besar guru menyetujui bahwa implementasi ESD dalam pembelajaran merupakan hal yang dirasa penting. Untuk itu, para guru berusaha untuk memperkaya pengetahuan dan pemahaman mereka terkait ESD dan SDGs melalui berbagai sumber, seperti artikel-artikel penelitian terkini pada jurnal, laman-laman situs terkait ESD, dan modul-modul ESD yang beredar dan dapat diakses melalui internet. Sebagian besar dari mereka juga akan mencoba merancang pembelajaran IPA yang akan diintegrasikan dengan kompetensikompetensi ESD pada topik-topik IPA tertentu.

\section{Simpulan}

Terdapat beberapa temuan pada studi pendahuluan terkait implementasi ESD dalam pembelajaran IPA pada tingkat SMP di Kabupaten Garut, yaitu: (1) Sebanyak 3 dari 12 guru sudah mengimplementasikan ESD dalam pembelajaran IPA dengan frekuensi minimal 2 kali; (2) Topik IPA yang sering digunakan dalam mengimplementasikan ESD oleh guru adalah topik bioteknologi. Untuk melihat bagaimana kemampuan guru IPA dalam mengimplementasikan ESD dan bagaimana kualitas implementasi ESD dalam pembelajaran IPA, perlu dilakukan penelitian lanjutan dengan jumlah responden yang lebih representatif. 


\section{Referensi}

Dannenberg, S., \& Grapentin, T. (2016). Education for sustainable development - Learning for transformation. The example of Germany. Journal of Futures Studies, 20(3), 7-20. https://doi.org/10.6531/JFS.2016.20(3).A7

Eilks, I. (2015). Science education and education for sustainable development - justifications, models, practices and perspectives. Eurasia Journal of Mathematics, Science and Technology Education, 11(1), 149-158. https://doi.org/10.12973/eurasia.2015.1313a

Hariyono, E., Abadi, A., Liliasari, L., Wijaya, A. F. C., \& Fujii, H. (2018). Designing Geoscience Learning for Sustainable Development: A Professional Competency Assessment for Postgraduate Students in Science Education Program. Jurnal Penelitian Fisika Dan Aplikasinya (JPFA), 8(2), 61. https://doi.org/10.26740/jpfa.v8n2.p61-70

Indrati, D. A., \& Hariadi, P. P. (2016). Esd ( Education for Sustainable Development ) Melalui Pembelajaran Biologi. Symposium on Biology Education, 371-382.

Jegstad, K. M., \& Sinnes, A. T. (2015). Chemistry Teaching for the Future: A model for secondary chemistry education for sustainable development. International Journal of Science Education, 37(4), 655-683. https://doi.org/10.1080/09500693.2014.1003988

Karaarslan, G., \& Teksöz, G. (2016). Integrating Sustainable Development Concept into Science Education Program. International Journal of Environmental Science Education, 11(15), 84038425 .

Klarin, T. (2018). The Concept of Sustainable Development: From its Beginning to the Contemporary Issues. Zagreb International Review of Economics and Business, 21(1), 67-94. https://doi.org/10.2478/zireb-2018-0005

Kyle, W. C. (2020). Expanding our views of science education to address sustainable development, empowerment, and social transformation. Disciplinary and Interdisciplinary Science Education Research, 2(1). https://doi.org/10.1186/S43031-019-0018-5

Novidsa, I., Purwianingsih, W., \& Riandi, R. (2020). Exploring knowledge of prospective biology teacher about Education for Sustainable Development. JPBI (Jurnal Pendidikan Biologi Indonesia), 6(2), 317-326. https://doi.org/10.22219/jpbi.v6i2.12212

Purnamasari, S., \& Hanifah, A. N. (2021). Education for Sustainable Development (ESD) dalam Pembelajaran IPA. JKPI: Jurnal Kajian Pendidikan IPA, I(2), 53-61. https://journal.uniga.ac.id/index.php/jkpi/article/view/1281

Rahman, A., Heryanti, L. M., \& Ekanara, B. (2019). Pengembangan Modul Berbasis Education for Sustainable Development pada Konsep Ekologi untuk Siswa Kelas X SMA. Jurnal Eksakta Pendidikan (Jep), 3(1), 1. https://doi.org/10.24036/jep/vol3-iss1/273

Rahmawati, S., Roshayanti, F., Nugroho, A. S., \& Hayat, M. S. (2021). Potensi implementasi Education for Sustainable Development ( ESD ) dalam pembelajaran IPA di MTs Nahdlatul Ulama Mranggen Kabupaten Demak. Jurnal Kualita Pendidikan, 2(1), 15-27.

Sund, P., \& Gericke, N. (2020). Teaching contributions from secondary school subject areas to education for sustainable development-a comparative study of science, social science and language teachers. Environmental Education Research, 26(6), 772-794. https://doi.org/10.1080/13504622.2020.1754341 
UNESCO. (2017). Education for Sustainable Development Goals: Learning Objectives. Education for Sustainable Development. The Global Education 2030 Agenda. http://www.unesco.org/openaccess/terms-\%0Ahttp://www.unesco.org/open-access/terms-use-ccbysa-en

UNESCO. (2018). Issues and Trends in Education for Sustainable Development. In UNESCO Publishing. https://www.bic.moe.go.th/images/stories/ESD1.pdf

UNESCO. (2020). Education for sustainable development: A Roadmap. https://doi.org/10.1111/j.2048416x.2009.tb00140.x

Wilujeng, I., Dwandaru, W. S. B., \& Rauf, R. A. B. A. (2019). The effectiveness of education for environmental sustainable development to enhance environmental literacy in science education: A case study of hydropower. Jurnal Pendidikan IPA Indonesia, 8(4), 521-528. https://doi.org/10.15294/jpii.v8i4.19948 